\title{
Mitral valve prolapse: a case report
}

\section{(1) Valentina Faletar \\ Živković*, \\ (1) Petra Zebić Mihić, \\ (C) Marul Ivandić, \\ (D) Lana Maričić, \\ (1) Kristina Selthofer- \\ Relatić, \\ DSandra Makarović}

University Hospital Centre Osijek, Osijek, Croatia
KEYWORDS: mitral valve prolapse, complication, heart failure.

CITATION: Cardiol Croat. 2018;13(5-6):197. | https://doi.org/10.15836/ccar2018.197

*ADDRESS FOR CORRESPONDENCE: Valentina Faletar Živković, Klinički bolnički centar Osijek, Huttlerova 4, HR-31000 0sijek, Croatia. / E-mail: valentina.faletar@gmail.com

ORCID: Valentina Faletar Živković, https://orcid.org/0000-0001-9072-8967

Petra Zebić Mihić, https://orcid.org/0000-0003-1302-6165 • Marul Ivandić, https://orcid.org/0000-0003-0716-5388

Lana Maričić, https://orcid.org/0000-0002-0311-8384 • Kristina Selthofer-Relatić, https://orcid.org/0000-0002-9890-6489 Sandra Makarović, https://orcid.org/0000-0002-7487-1189

|IIIIIIIIIIIIIIIIIIIIIIIIIIIIIIIIIIIIIIIIIIIIIIIIIIIIIIIIIIIIIIIIIIIIIIIIIIIIIIIIIIIIIIIIIIIIIIIIIIIIIIIIIIIIIIIIIII

Introduction: Mitral valve prolapse (MVP) is a condition in which one or both mitral flaps of the mitral valve (MV) do not close smoothly or evenly, but instead bulge (prolapse) upward into the left atrium. It is relatively rare (frequency is $1-2 \%$ ), and the highest percentage of patients is asymptomatic. Only a small number of patients reported palpitations, anxiety, tiredness, and atypical chest pain. An echocardiogram is a "gold standard" in diagnosing this disease. Complications are rare, and the most common and most important is mitral regurgitation. Asymptomatic patients should not be treated. Symptomatic patients need to be closely monitored clinically and ultrasonically, and surgical reconstruction of valves is considered in patients with severe mitral regurgitation ${ }^{1,2}$

Case report: 52-years-old female patient has heart murmur since childhood but so far has not been cardiologically treated. A few months ago, she felt chest pain spreading to her neck and intolerance of physical activity. The complete prolapse of the posterior MV has been diagnosed by echocardiography, with the suspected rupture of the chord, severe mitral insufficiency, consequently significant dilated left atrium, initially dilated left ventricle with still preserved left ventricular systolic function (LVEF $54 \%$, and the signs of moderate pulmonary hypertension. Cardiac surgery was performed in our centre because of patient preference, and a mitral valve was replaced. Control echocardiography showed adequate position mechanical mitral valve with the non-parabolic flow and preserved systolic function of (LVEF 53\%). On a follow-up visit the patient was subjectively well, without symptoms.

Conclusion: Mitral valve prolapse is usually asymptomatic condition that requires no treatment and only needs to be monitored. It occasionally causes serious complications in form of mitral regurgitation that can lead to congestive heart failure. Those patients require medical treatment which includes oral medications or, in case of severe mitral regurgitation, mitral valve repair or surgical replacement. Early detection and periodic monitoring are recommended.
RECEIVED:

April 28, 2018

ACCEPTED:

May 10, 2018

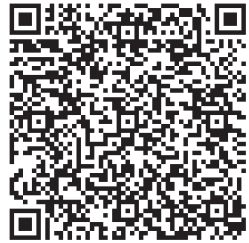

LITERATURE IIIIIIIIIIIIIIIIIIIIIIIIIIIIIIIIIIIIIIIIIIIIIIIIIIIIIIIIIIIIIIIIIIIIIIIIIIIIIIIIIIIIIIIIIIIIIIIIIII

1. $\quad$ Mirat J, Ćorić V, et al. Bolesti srčanih zalistaka. Zagreb: Nakladni zavod Globus, 2011.

2. Devereux RB, Kramer-Fox R, Kligfield P. Mitral valve prolapse: causes, clinical manifestations, and management. Ann Intern Med. 1989 Aug 15;111(4):305-17. https://doi.org/10.7326/0003-4819-111-4-305 